\title{
APRIORI ALGORITHM FOR DETERMINING THE DEMAND LEVEL OF STATIONARY PT. MAIN GAFA INDONESIA
}

\author{
Sri Wahyuni 1; Wulan Dari ${ }^{2 *}$; Lusa Indah Prahartiwi ${ }^{3}$ \\ Information System \\ STMIK Nusa Mandiri \\ www.nusamandiri.ac.id \\ yuniiw27@gmail.com¹; wulan.wld@nusamandiri.ac.id²; lusa.lip@nusamandiri.ac.id³
}

$\left(^{*}\right)$ Corresponding Author

\begin{abstract}
PT Gafa Utama Indonesia is one company that provides services in teaching and writing. Until now, PT Gafa Utama Indonesia already has 30 well-known branches in Jabodetabek. In the teaching and learning process, Gafa needs some stationery and teaching aids. The high demand for office stationery, and the mismatch of inventory in the warehouse, affect the fluency in the teaching and learning process. The data used in this study is the report data on the demand for office stationery for the period January-December 2018. This study uses a priori algorithm method and assessment with Tanagra tools. The results of manual calculations with Microsoft Excel are the same as those using the Tanagra tool. The final result shows the 2 items with the most demand, namely an eraser and a sharpener with at least $50 \%$ support, and $50 \%$ confidence. These results can be used as a reference for PT Gafa Utama Indonesia in the supply of office stationery.
\end{abstract}

Keywords: Apriori Algorithms, Decision Support System, Demand for Office Stationery

Abstrak- PT Gafa Utama Indonesia merupakan
salah satu perusahaan yang memberikan pelayanan
dalam mengajarkan baca dan tulis. Sampai dengan
saat ini PT Gafa Utama Indonesia telah mempunyai
30 cabang yang tersebar di Jabodetabek. Dalam
proses kegiatan belajar mengajar, Gafa memerlukan
beberapa alat tulis dan alat peraga. Banyaknya
permintaan barang alat tulis kantor, dan
ketidaksesuaian persediaan barang di gudang,
mempengaruhi ketidaklancaran dalam proses
kegiatan belajar mengajar. Data yang digunakan
pada penelitian ini merupakan data laporan
permintaan barang alat tulis kantor periode
Januari-Desember 2018 . Penelitian ini
menggunakan metode algoritma apriori dan
pengkajian dengan tools tanagra. Hasil perhitungan
manual dengan Microsoft Excel sama dengan hasil
perhitungan menggunakan tools tanagra. Hasil
akhir menunjukkan 2 barang dengan permintaan
terbanyak yaitu penghapus dan rautan dengan minimum support $50 \%$, dan confidence $50 \%$. Hasil tersebut dapat digunakan sebagai acuan PT Gafa Utama Indonesia dalam persediaan barang alat tulis kantor.

Kata Kunci: Algoritma Apriori, Sistem Pendukung Keputusan, Permintaan Barang ATK.

\section{INTRODUCTION}

The stock availability system in the company's warehouse is a procedure and management method that is interrelated in the operational activities of a company. One of the main activities carried out by the company is an inventory control activity. This is due to a considerable influence a company in the event of a failure in inventory control.

PT Gafa Utama Indonesia is a company that operates and provides services in the field of education (Wulandari \& Pramono, 2018). Gafa as a company provides services in the form of teaching writing and reading for children starting from the age of 3 years. The process of teaching and learning activities carried out in the classroom using stationery and teaching aids. Gafa, until now has 30 branches in Jakarta, Depok, Tangerang, Bekasi and Bogor.

Of the many Gafa branches, which are $30 \mathrm{Gafa}$ branches in the Jabodetabek area, there are many requests for goods in the form of office stationery, which used for teaching and learning activities. With conditions related to the current number of requests that are not by the fewer supplies of office stationery. This can result in influencing the nonfluency in the process of teaching and learning activities.

Gafa currently does not have a standard to measure the level of demand for goods with the inventory of goods in the warehouse. The system implemented by Gafa only based on estimates from logistics staff regarding the availability of stationery 
stock in the warehouse. Therefore, Gafa needs a decision support system to improve services.

The availability of a large amount of sales data is not used optimally because there is no decision support system and methods that can be used to design a business strategy in increasing sales activities (Sikumbang, 2018).

Data mining or often referred to as Knowledge Discovery in Database (KDD) is an activity related to data collection, historical in gaining knowledge, data use, and determining relationship patterns in the use of large data (Baulolo, 2020). Data mining serves to identify a fact and suggested conclusions based on filtering through data to explore data patterns or anomalies (Widiastuti \& Sofi, 2014). Data mining can also be interpreted as a data mining process that produces an output in the form of knowledge (Nofriansyah \& Nurcahyo, 2015). With data mining that is used to extract important information hidden in a large enough dataset, knowledge will be obtained in a large enough data set (Rodiyansyah, 2015).

Shopping cart analysis can be used to analyze a consumer's shopping pattern (Panjaitan, Surahman, \& Rosmalasari, 2020). The real effect of shopping basket analysis is that there is an increase in sales for small/retail traders by arranging items that are often purchased together near each other. This placement strategy can increase purchases and also help ensure that shoppers who buy these items don't forget to buy other items just because they didn't see them. In addition, consumers will also be able to feel comfortable because the items to be purchased together are placed close together, which will increase the satisfaction value of the buyer (Haryanto, Oslan, \& Dwiyana, 2011).

Association Rule Mining is a data mining method that focuses on finding purchasing patterns by extracting transactional data from a store (Ghozali, Ehwan, \& Sugiharto, 2017). Association Rule Mining or this association analysis is a data mining technique in finding an associative rule between combinations (Tampubolon et al., 2013).

Several studies have been conducted by researchers in analyzing shopping carts using the Apriori Algorithm and Hash-Based Algorithm.

Related research regarding the implementation of data mining with the Apriori algorithm is in determining drugs purchasing patterns. The result of the study is the system that has been built can show a result that meets the needs in determining the pattern of purchasing drugs, namely based on the tendency of buying drugs by customers (Yanto \& Khoiriah, 2015).

The next related research is the analysis of the Apriori algorithm on the pattern of borrowing books at the ITB Ahmad Dahlan library, the purpose of this research is to utilize the apriori algorithm and use the Tanagra software to classify the data on borrowing books at the ITB Ahmad Dahlan library. The results of this study are known which books are most often borrowed together, with a minimum support value of $5 \%$, and a minimum confidence value of $10 \%$ in the form of Tax Accounting books, and for Taxation books, it is with a minimum support value of $7.30 \%$, and a minimum confidence value of $62,79 \%$, and can be used as a reference for the library on the Ahmad Dahlan ITB Campus in the procurement and placement of book layouts (Satie, Suparni, \& Pohan, 2020).

Based on the background of the problem above, the Apriori algorithm can be used as a reference in preparing office stationery supplies and describing how to determine the stock of office stationery at the warehouse of PT Gafa Utama Indonesia. The Apriori algorithm can assist in forming a candidate combination of items, then testing activities are carried out whether the item combination meets the value of the minimum support and confidence parameters which are the threshold values determined by the user (Yanto \& Khoiriah, 2015). This apriori algorithm uses knowledge including frequent itemsets that are already known initially in processing the next information, and this a priori algorithm can also determine the likely candidates to appear by taking into account the minimum support value (Sepri \& Afdal, 2017). In addition, the Apriori algorithm has a faster time in mining data compared to the hashbased algorithm (Destiyati \& Aribowo, 2015).

\section{MATERIALS AND METHODS}

Based on Figure 1, the stages of the research method carried out are as follows:

1. Dataset Collection

This study focuses reports on demand for stationery goods in one branch, namely, branch 20 . The reason for the researcher was choosing branch 20 , is because branch 20 is Gafa's largest branch. Thus, these 20 branches have the most stationery of request data compared to other branches. Researchers will also use the results of applying the apriori algorithm to branch 20 as a reference for all Gafa branches. The data used in this study is primary data. This primary data source was obtained from the report on demand for stationery goods at branch 20 for the period JanuaryDecember 2018 at PT Gafa Utama Indonesia. The dataset used has 7 attributes, including black pens, pen content, tip ex, eraser, colored pencils, writing pencils, and sharpeners. 


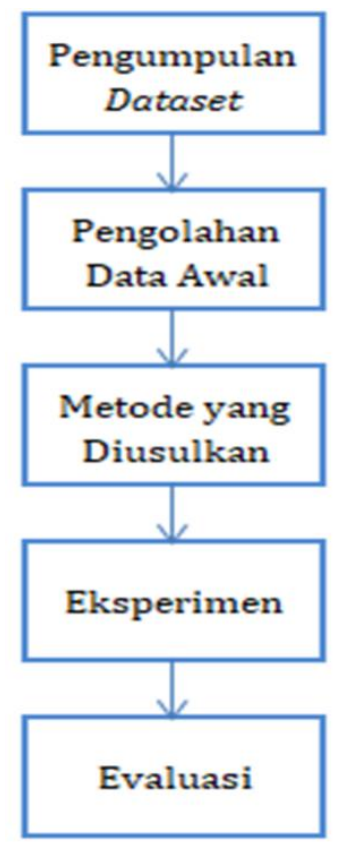

Figure1. Research Methodology

\section{Initial Data Processing}

Data processing uses the Apriori Algorithm whose calculations are carried out manually by making tabular into Microsoft Excel (Satie et al., 2020).

\section{Proposed Method}

The method proposed in this study is to use an apriori algorithm, then look for minimum support and minimum confidence. If the value of both of them is fulfilled, a final association rule will be formed which is the purpose of this study. To avoid an error that may appear when performing manual calculations. So the Tanagra tools are used to reexamine. Tanagra is a free data mining tool for academic purposes and this research proposes data mining methods from data exploration analysis, database creation, and statistical data processing. (Badrul, 2016; Ulkhairi \& Hutabri, 2020)

\section{Experiment}

The experiment was carried out by processing the demand for office stationery items using the Apriori Algorithm. Then the experimental results of the algorithm will be tested using the Tanagra tool. 5. Evaluasi

The proposed method will tested to find out what office stationery items have support and confidence values higher than the minimum standard of support and confidence.

Table 1. Data Request for Stationery Goods Branch Office 20

\begin{tabular}{ccc}
\hline Month & Transaction Items & $\begin{array}{c}\text { Number of } \\
\text { Items }\end{array}$ \\
\hline January & - & - \\
\hline
\end{tabular}

\begin{tabular}{|c|c|c|}
\hline Month & Transaction Items & $\begin{array}{c}\text { Number of } \\
\text { Items }\end{array}$ \\
\hline \multirow{6}{*}{ February } & Writing Pencil & 8 \\
\hline & Eraser & 20 \\
\hline & Colored Pencils & 6 \\
\hline & Black Pen & 2 \\
\hline & Sharpener & 15 \\
\hline & Type X & 1 \\
\hline \multirow{5}{*}{ March } & Writing Pencil & 6 \\
\hline & Colored Pencils & 4 \\
\hline & Cartridge & 5 \\
\hline & Sharpener & 15 \\
\hline & Type X & 2 \\
\hline \multirow{5}{*}{ April } & Eraser & 20 \\
\hline & Writing Pencil & 6 \\
\hline & Colored Pencils & 3 \\
\hline & Cartridge & 2 \\
\hline & Rautan & 20 \\
\hline \multirow{5}{*}{ May } & Eraser & 15 \\
\hline & Writing Pencil & 6 \\
\hline & Colored Pencils & 3 \\
\hline & Sharpener & 15 \\
\hline & Black Pen & 3 \\
\hline \multirow{5}{*}{ June } & Eraser & 20 \\
\hline & Writing Pencil & 6 \\
\hline & Black Ballpoint & 3 \\
\hline & Black Pen & 3 \\
\hline & Sharpener & 15 \\
\hline \multirow{5}{*}{ July } & Eraser & 10 \\
\hline & Writing Pencil & 10 \\
\hline & Colored Pencils & 10 \\
\hline & Black Pen & 4 \\
\hline & Cartridge & 5 \\
\hline \multirow{3}{*}{ August } & Eraser & 15 \\
\hline & Writing Pencil & 6 \\
\hline & Sharpener & 10 \\
\hline \multirow{3}{*}{ September } & Writing Pencil & 6 \\
\hline & Colored Pencils & 6 \\
\hline & Cartridge & 4 \\
\hline \multirow{5}{*}{ October } & Eraser & 20 \\
\hline & Writing Pencil & 6 \\
\hline & Colored Pencils & 4 \\
\hline & Cartridge & 4 \\
\hline & Sharpener & 14 \\
\hline \multirow{4}{*}{ November } & Eraser & 15 \\
\hline & Writing Pencil & 6 \\
\hline & Black Pen & 9 \\
\hline & Sharpener & 15 \\
\hline \multirow{4}{*}{ December } & Eraser & 15 \\
\hline & Writing Pencil & 10 \\
\hline & Colored Pencils & 1 \\
\hline & Sharpener & 10 \\
\hline
\end{tabular}

Table 1. is the data on demand for stationery goods at PT. Gafa Utama Indonesia Branch 20, with the period February-December 2018.

\section{RESULT AND DISCUSSION}

Determination of the minimum support value is carried out by taking the accumulated demand for office stationery items obtained from monthly requests by taking the 3 most frequently requested items in each month, as shown in Table 2. 
Table 2. Transaction Patterns for Office Stationery Requests

\begin{tabular}{cl}
\hline Month & \multicolumn{1}{c}{ Itemset } \\
\hline 1 & - \\
\hline 2 & Eraser, Sharpener, Writing Pencil \\
\hline 3 & Sharpener, Writing Pencil, Cartridge \\
\hline 4 & Eraser, Sharpener, Writing Pencil \\
\hline 5 & Eraser, Sharpener, Writing Pencil \\
\hline 6 & Eraser, Sharpener, Writing Pencil \\
\hline 7 & Eraser, Writing Pencil, Colored Pencil \\
\hline 8 & Eraser, Sharpener, Writing Pencil \\
\hline 9 & Writing Pencil, Colored Pencil, Cartridge \\
\hline 10 & Eraser, Sharpener, Writing Pencil \\
\hline 11 & Eraser, Sharpener, Black Pen \\
\hline 12 & Eraser, Writing Pencil, Sharpener
\end{tabular}

Based on Table 2. the results of the transaction pattern for the demand for office stationery, there were 11 transactions, because in January there was no demand for office stationery. The next step is to make a tabular format of monthly transaction data on the demand for office stationery items which makes it easier to find out how many items are requested for each transaction, which is shown in Table 3.

Table 3. Transaction Data Tabular

\begin{tabular}{|c|c|c|c|c|c|c|c|}
\hline $\begin{array}{l}\mathrm{N} \\
\mathrm{o}\end{array}$ & $\begin{array}{c}\text { Era } \\
- \\
\text { ser }\end{array}$ & $\begin{array}{c}\text { Writin } \\
\text { g } \\
\text { Pencil } \\
\text { s }\end{array}$ & $\begin{array}{l}\text { Colore } \\
\text { d } \\
\text { Pencil } \\
\text { s }\end{array}$ & $\begin{array}{c}\text { Blac } \\
\text { k } \\
\text { Pen }\end{array}$ & $\begin{array}{c}\text { Car- } \\
\text { tridg } \\
\text { e }\end{array}$ & $\begin{array}{c}\text { Shar } \\
- \\
\text { pene } \\
r\end{array}$ & $\begin{array}{c}\mathrm{Ti} \\
\mathrm{p} \\
\mathrm{Ex}\end{array}$ \\
\hline 1 & 1 & 1 & 0 & 0 & 0 & 1 & 0 \\
\hline 2 & 1 & 0 & 0 & 0 & 1 & 1 & 0 \\
\hline 3 & 1 & 1 & 0 & 0 & 0 & 1 & 0 \\
\hline 4 & 1 & 1 & 0 & 0 & 0 & 1 & 0 \\
\hline 5 & 1 & 1 & 0 & 0 & 0 & 1 & 0 \\
\hline 6 & 1 & 1 & 1 & 0 & 0 & 0 & 0 \\
\hline 7 & 0 & 1 & 1 & 0 & 1 & 0 & 0 \\
\hline 8 & 1 & 1 & 0 & 0 & 0 & 1 & 0 \\
\hline 9 & 1 & 1 & 0 & 0 & 0 & 1 & 0 \\
\hline $\begin{array}{l}1 \\
0\end{array}$ & 1 & 0 & 0 & 1 & 0 & 1 & 0 \\
\hline $\begin{array}{l}1 \\
1\end{array}$ & 1 & 1 & 0 & 0 & 0 & 1 & 0 \\
\hline
\end{tabular}

The support value with the minimum amount of support $=50 \%$. The support value of 1 item is obtained by the formula:

Support $(A)=\frac{\sum \text { Transaksi yang mengandung A }}{\sum \text { Transaksi }} \times 100 \%$ Table 4.

The support value of an item can be seen in

Table 4. Support 1 Itemset

\begin{tabular}{cc}
\hline 1 Itemset & Support \\
\hline Eraser & $83.33 \%$ \\
\hline Writing Pencil & $75 \%$ \\
\hline Sharpener & $75 \%$ \\
\hline Colored Pencils & $16.67 \%$ \\
\hline Cartridge & $16.67 \%$ \\
\hline
\end{tabular}

\begin{tabular}{cc}
\hline Black Pen & $8.33 \%$ \\
\hline
\end{tabular}

The support value of 2 items is obtained by the following formula:

Support $(\mathrm{A} n \mathrm{~B})=\frac{\sum \text { Transaksi yang mengandung A dan B }}{\sum \text { Transaksi }} \times 100 \% \ldots \ldots \ldots \ldots . . .(2)$

The support value of the two items in this study can be seen in Table 5 .

Table 5. Support 2 Itemset

\begin{tabular}{lc}
\hline \multicolumn{1}{c}{ Itemset } & Support \\
\hline Eraser, Writing Pencil & $73 \%$ \\
\hline Eraser, Sharpener & $82 \%$ \\
\hline Eraser, Colored Pencils & $9 \%$ \\
\hline Eraser, Cartridge & $9 \%$ \\
\hline Eraser, Black Pen & $9 \%$ \\
\hline Writing Pencil, Sharpener & $63.64 \%$ \\
\hline Writing Pencil, Colored Pencils & $18.18 \%$ \\
\hline Writing Pencil, Cartridge & $9.09 \%$ \\
\hline Sharpener, Cartridge & $9.09 \%$ \\
\hline Sharpener, Black Pen & $9.09 \%$ \\
\hline Colored Pencils, Cartridge & $9 \%$ \\
\hline
\end{tabular}

The specified minimum support value is $50 \%$, so the combination of 2 itemsets that do not meet the minimum support will be removed as shown in Table 6.

Table 6. Support 2 Itemset 50\%

\begin{tabular}{lc}
\hline \multicolumn{1}{c}{ Itemset } & Support \\
\hline Eraser, Writing Pencil & $73 \%$ \\
\hline Eraser, Sharpener & $82 \%$ \\
\hline Writing Pencil, Sharpener & $63.64 \%$ \\
\hline
\end{tabular}

The value of the support for the three items in the table can be seen in table 7 .

Table 7. Support 3 Itemset

\begin{tabular}{lc}
\hline Itemset & Support \\
\hline Eraser, Writing Pencil, Sharpener & $64 \%$ \\
\hline Eraser, Writing Pencil, pensil warna & $9 \%$ \\
\hline Eraser, Writing Pencil, Cartridge & $0 \%$ \\
\hline Eraser, Writing Pencil, Black Pen & $0 \%$ \\
\hline Eraser, Sharpener, Colored Pencil & $0 \%$ \\
\hline Eraser, Sharpener, Cartridge & $9 \%$ \\
\hline Eraser, Sharpener, Black Pen & $9 \%$ \\
\hline Eraser, Colored Pencil, Cartridge & $0 \%$ \\
\hline Eraser, Colored Pencil, Black Pen & $0 \%$ \\
\hline Writing Pencil, Sharpener, Colored Pencil & $0 \%$ \\
\hline Writing Pencil, Sharpener, Cartridge & $0 \%$ \\
\hline Writing Pencil, Sharpener, Black Pen & $0 \%$ \\
\hline Writing Pencil, Colored Pencil, Cartridge & $9 \%$ \\
\hline Colored Pencil, Cartridge, Black Pen & $0 \%$ \\
\hline
\end{tabular}

The minimum support specified is $50 \%$. None of the three item-set combinations meet the minimum support. Then the two-item set combinations will be used for association formation.

Association and confidence rules, because only 2 itemsets meet the minimum support requirements, the confidence value is sought from 2 itemset combinations. After all the high-frequency 
patterns are found, then look for association rules that meet the minimum confidence requirements or A B associations. Then a minimum confidence rule of $50 \%$ is determined. The confidence value is obtained by the following formula.

Confidence $(\mathrm{A} \cap \mathrm{B})$

$=\frac{\sum \text { Transaksi yang mengandung A dan B }}{\sum \text { Transaksi }} \times 100 \%$

With the combination of 2 itemsets that have been determined, it can be seen the magnitude of the support and confidence values of the candidate association rules, as shown in Table 8.

Table 8. Candidate Association Rules 2 Itemset

\begin{tabular}{lcc}
\hline \multicolumn{1}{c}{ Rules } & Support & Confidence \\
\hline $\begin{array}{l}\text { If you ask for an eraser, you will ask } \\
\text { for a writing pencil }\end{array}$ & $72.73 \%$ & $80 \%$ \\
\hline $\begin{array}{l}\text { If it asks for an eraser, it will ask for } \\
\text { a sharpener }\end{array}$ & $81.82 \%$ & $90 \%$ \\
\hline $\begin{array}{l}\text { If you ask for an eraser, it will ask } \\
\text { for colored pencils }\end{array}$ & $9.09 \%$ & $10 \%$ \\
\hline $\begin{array}{l}\text { If it asks for an eraser, it will ask for } \\
\text { the contents of the pen }\end{array}$ & $9.09 \%$ & $10 \%$ \\
\hline $\begin{array}{l}\text { If it asks for an eraser, it will ask for } \\
\text { a black pen }\end{array}$ & $9.09 \%$ & $10 \%$ \\
\hline $\begin{array}{l}\text { If you ask for a writing pencil, you } \\
\text { will ask for a sharpener }\end{array}$ & $63.64 \%$ & $77.78 \%$ \\
\hline $\begin{array}{l}\text { If you ask for writing pencils, you } \\
\text { will ask for colored pencils }\end{array}$ & $18.18 \%$ & $22.22 \%$ \\
\hline $\begin{array}{l}\text { If you ask for a writing pencil, you } \\
\text { will ask for the contents of the pen }\end{array}$ & $9.09 \%$ & $11.11 \%$ \\
\hline $\begin{array}{l}\text { If you ask for a sharpener, you will } \\
\text { ask for the contents of the pen }\end{array}$ & $9.09 \%$ & $11.11 \%$ \\
\hline $\begin{array}{l}\text { If you ask for a sharpener, you will } \\
\text { ask for a black pen }\end{array}$ & $9.09 \%$ & $11.11 \%$ \\
\hline $\begin{array}{l}\text { If you ask for colored pencils, you } \\
\text { will ask for the contents of the pens }\end{array}$ & $9.09 \%$ & $50 \%$ \\
\hline
\end{tabular}

The association rules are based on the minimum support value of $50 \%$ and the minimum value of $50 \%$ confidence, it can be seen in Table 9 . below:

Table 9. 2 Itemset Association Rules

\begin{tabular}{lcc}
\hline \multicolumn{1}{c}{ Rules } & Support & Confidence \\
\hline $\begin{array}{l}\text { If you ask for an Eraser, it will ask } \\
\text { for a writing pencil }\end{array}$ & $72.73 \%$ & $80 \%$ \\
\hline $\begin{array}{l}\text { If you ask for an Eraser, it will ask } \\
\text { for a Sharpener }\end{array}$ & $81.82 \%$ & $90 \%$ \\
\hline $\begin{array}{l}\text { If you ask for a writing pencil, } \\
\text { you will ask for a sharpener }\end{array}$ & $63.64 \%$ & $77.78 \%$ \\
\hline
\end{tabular}

Experiments using the apriori algorithm on the demand dataset for office stationery were carried out using the Tanagra tools. The minimum support is set at $50 \%$ and the minimum confidence is set at $50 \%$.

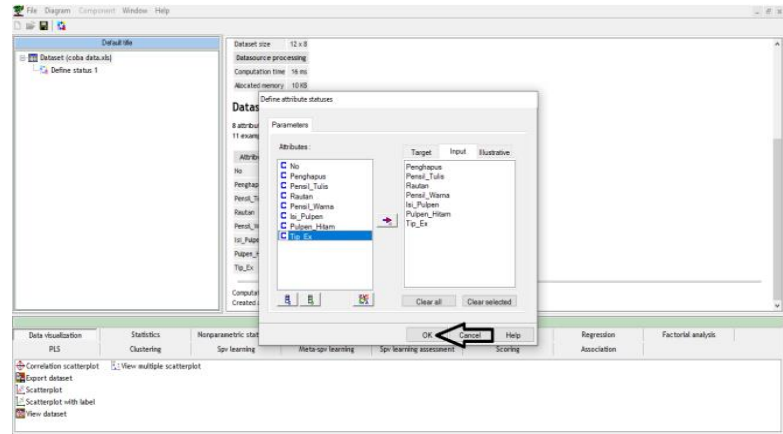

Figure 2. Required Attribute Input Process

Figure 2. Shows the attribute input process into the Tanagra tool. There are 7 attributes entered, namely Eraser, Pencil_Write, Sharpener, Pencil_Color, Fill_Pen, Pen_Black, and Tip_Ex. As for the No attribute, it is not included because the attribute is not needed in the data processing process.

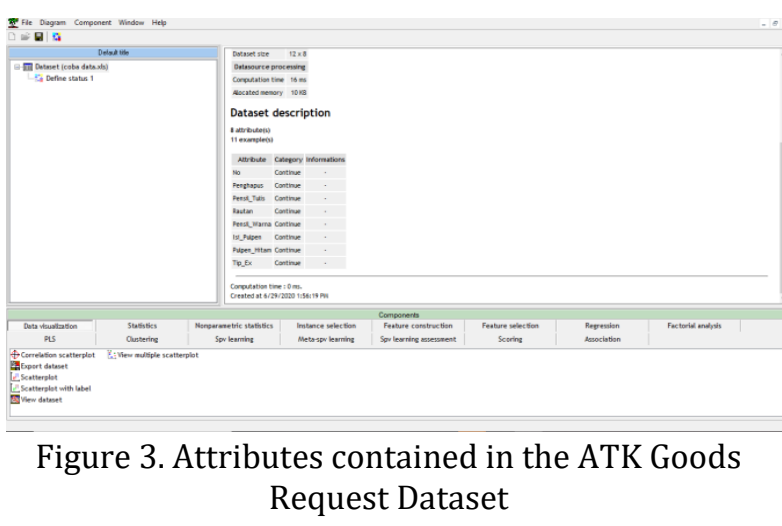

Figure 3. shows the attributes contained in the ATK item request dataset after being entered into the Tanagra tool.

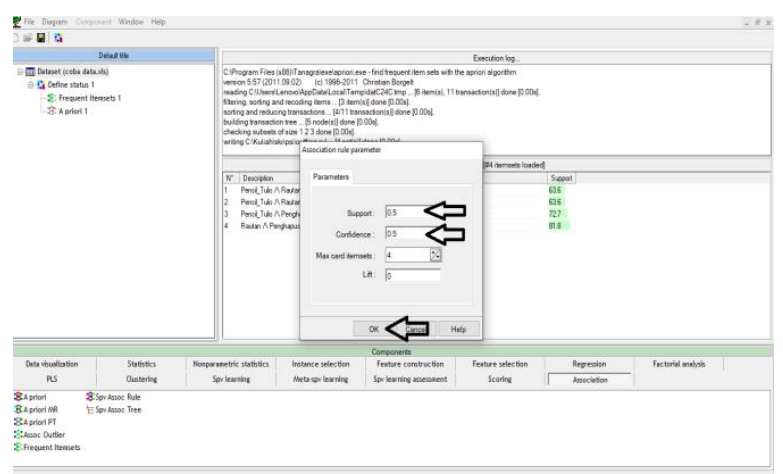

Figure 4. The Process of Determining Minimum Support and Minimum Confidence

The next process is the determination of Minimum Support and Minimum Confidence as shown in Figure 4. The results of the Apriori Algorithm experiment on the demand dataset for office stationery using the Tanagra tool are shown in Figure 5.

P-ISSN: 1978-2136 | E-ISSN: 2527-676X

Techno Nusa Mandiri : Journal of Computing and Information Technology As an Accredited Journal Rank 4 based on SK Dirjen Risbang SK No. 85/M/KPT/2020 


\section{RULES}

\begin{tabular}{|c|c|c|c|c|}
\hline \multicolumn{5}{|c|}{ Number of rules : 12} \\
\hline$N^{*}$ Antecedent & Consequent & Lift & Support (:) & Confidence (\%) \\
\hline 1 "Rautan=true" & "Penghapus=true" & 1.10000 & 81.818 & 100.000 \\
\hline 2 "Penghapuss=true" & "Rautan=true" & 1.10000 & 81.818 & 90.000 \\
\hline 3 "Rautan=true" - "Pensil_Tuisstrue" & "Penghapus=true" & 1.10000 & 63.636 & 100.000 \\
\hline 4 "Penghapus=true" & "Rautan=true" - "Pensil_Tuis=true" & 1.10000 & 63.636 & 70.000 \\
\hline 5 "Rautan=true" & "Penghapus=true" - "Pensil_Tuis=true" & 1.06944 & 63.636 & 77.778 \\
\hline 6 "Penghapus=true" - "Pensil_Tulis=true" & "Rautan=true" & 1.06944 & 63.636 & 87.500 \\
\hline 7 "Pensil_Tuis=true" & "Penghapus=true" & 0.97778 & 72.727 & 88.889 \\
\hline 8 "Penghapus =true" & "Pensil_Tulis=true" & 0.97778 & 72.727 & 80.000 \\
\hline 9 "Pensil_Tulis=true" & "Rautan=true" & 0.95062 & 63.636 & 77.778 \\
\hline 10 "Rautan=true" & "Pensil_Tuis=true" & 0.95062 & 63.636 & 77.778 \\
\hline 11 "Pensil_Tuisstrue" & "Penghapus=true" - "Rautan=true" & 0.95062 & 63.636 & 77.778 \\
\hline 12 "Penghapus=true" - "Rautan=true" & "Pensi__Tulis=true" & 0.95062 & 63.636 & 77.778 \\
\hline
\end{tabular}

Figure 5. Experimental Results of Apriori Algorithm Using Tanagra Tools

In Figure 5. it can be seen that the transaction data for ATK goods requests with a Minimum Support of $50 \%$ and Minimum Confidence of 50\% have obtained a result that becomes a frequent itemset, namely a combination of the Eraser, Rautan, and Pensil_Tulis itemsets. The percentage of the resulting support value is the Eraser and Sharpener of $81.818 \%$. The Lift Ratio obtained from the combination of the Eraser and Sharpener itemsets is 1.10000 . Because the results of the Lift Ratio that have been obtained are more than 1, it shows that there is a benefit from these rules.

\section{CONCLUSION}

Based on the research that has been done, it can be concluded that the application of the a priori algorithm method is used to conduct experiments on the dataset of demand for office stationery. The experimental results using manual calculations using Microsoft Excel and Tanagra tools obtained association rules or rules from the itemset combination. The Eraser and Sharpener as Frequent itemset with the resulting support of $81.818 \%$. The Lift Ratio value obtained is 1.10000 , which means that there are benefits from the association rules or these rules. In addition, a pattern of demand for office stationery items is required by each branch in the form of demand data according to the needs of the branches at PT Gafa Utama Indonesia. The results of this study are used as a reference in the supply of office stationery in the next period. This research has been done so that there is no difference between the stock of office stationery and the demand for office stationery goods at each branch.

\section{REFERENCE}

Badrul, M. (2016). Algoritma asosiasi dengan algoritma apriori untuk analisa data penjualan. Pilar Nusa Mandiri, 13(2), 121-129. Retrieved from http://ejournal.nusamandiri.ac.id/index.php /pilar/article/view/266

Baulolo, E. (2020). Data Mining Untuk Perguruan Tinggi. Deepublish.

Destiyati, O. S. A., \& Aribowo, E. (2015). Analisis Perbandingan Algoritma Apriori Dan Algoritma Hash Based Pada Market Basket Analysis di Apotek UAD. Jurnal Sarjana Teknik Informatika, 3.

Ghozali, M. I., Ehwan, R. Z., \& Sugiharto, W. H. (2017). Analisa Pola Belanja Menggunakan Algoritma Fp Growth, Self Organizing Map (Som) Dan K Medoids. Simetris: Jurnal Teknik Mesin, Elektro Dan Ilmu Komputer, 8(1), 317-326. https://doi.org/10.24176/simet.v8i1.995

Haryanto, D., Oslan, Y., \& Dwiyana, D. (2011). Implementasi Analisis Keranjang Belanja Dengan Aturan Asosiasi Menggunakan Algoritma Apriori Pada Penjualan Suku Cadang Motor. Jurnal Buana Informatika, 2(2), 81-94.

https://doi.org/10.24002/jbi.v2i2.311

Nofriansyah, D., \& Nurcahyo, G. W. (2015). Algoritma Data Mining Dan Pengujian. Deepublish.

Panjaitan, F., Surahman, A., \& Rosmalasari, T. D. (2020). Analisis Market Basket Dengan Algoritma Hash-Based Pada Transaksi Penjualan (Studi Kasus: TB. Menara). Jurnal Teknologi Dan Sistem Informasi (JTSI), 1(2), 111-119.

Rodiyansyah, S. (2015). Algoritma Apriori untuk Analisis Keranjang Belanja pada Data Transaksi Penjualan. Infotech Journal, 1(2). Retrieved from http://www.jurnal.unma.ac.id/index.php/inf otech/article/view/42

Satie, D. E., Suparni, S., \& Pohan, A. B. (2020). Analisa Algoritma Apriori Pada Pola Peminjaman Buku di Perpustakaan ITB Ahmad Dahlan. Jurnal Media Informatika Budidarma, 4(1), 136.

https://doi.org/10.30865/mib.v4i1.1475

Sepri, D., \& Afdal, M. (2017). Analisa Dan Perbandingan Metode Algoritma Apriori Dan Fp-Growth Untuk Mencari Pola Daerah Strategis. Jurnal Sistem Informasi Kaputama (JSIK), 1(1), 47-55.

Sikumbang, E. D. (2018). Penerapan Data Mining Penjualan Sepatu Menggunakan Metode Algoritma Apriori. Jurnal Teknik Komputer AMIK BSI (JTK), Vol 4, No.(September), 1-4.

Tampubolon, K., Saragih, H., Reza, B., Epicentrum, K., Asosiasi, A., \& Apriori, A. (2013). 
Implementasi Data Mining Algoritma Apriori Pada Sistem Persediaan Alat-Alat Kesehatan. Majalah Ilmiah Informasi Dan Teknologi Ilmiah (INTI), 1(1), 93-106. Retrieved from http://vokasi.uho.ac.id/teknik-

arsitektur/assets/download/151212042307

17. Jurnal Kenendy.pdf

Ulkhairi, M., \& Hutabri, E. (2020). Implementasi Data Mining Penjualan Kosmetik Dengan Algoritma Apriori. Computer and Science Industrial Engineering (COMASIE), 3(3), 102111. Retrieved from http://ejournal.upbatam.ac.id/index.php/co masiejournal/article/view/2185/

Widiastuti, D., \& Sofi, N. (2014). Analisis Perbandingan Algoritma Apriori Dan FpGrowth Pada Transaksi Koperasi. UG Jurnal Vol., 8(01), 21-24.

Wulandari, S., \& Pramono, H. (2018). Penerapan Pengolahan Limbah Pengalengan Rajungan (Portunus Pelagicus) di PT . Sumber Mina Bahari Rembang Jawa Tengah Processing of waste of canning and swimming crab (Portunus pelagicus ) in Tempat dan Waktu Penelitian yang. 7(2), 78-88.

Yanto, R., \& Khoiriah, R. (2015). Implementasi Data Mining dengan Metode Algoritma Apriori dalam Menentukan Pola Pembelian Obat. Creative Information Technology Journal, 2(2), 102.

https://doi.org/10.24076/citec.2015v2i2.41 
